\title{
Progressive Geopolitics
}

\author{
Gerry Kearns*
}

School of Public and International Affairs, Virginia Tech

\section{Abstract}

Conservative geopolitics has assumed that the primary agents that matter in world affairs are states and, furthermore, that the primary relations that structure the world are those of force. Progressive geopolitics needs to question both assumptions. In this article, I explore some of the things that matter other than states and some of the relations that count other than force.

\section{Introduction}

Geopolitics developed as an adjunct to statecraft and has focused primarily on states and on their use of force against each other. Teggart (1919) referred to the connection with favour in 'Geography as an Aid to Statecraft', his appreciation of Mackinder's (1919) famous volume of advice for the Versailles Peace Conference. From the Olympian heights of political science, Clokie (1944, 502), reviewing among other things a reprint of Mackinder's book, disparaged geopolitics as, '[a]t best [...] no more than statecraft, with emphasis on the craft.' Lacoste $(2005,6)$, for one, defines geopolitics as 'the territorial struggle of powers'. ${ }^{1}$ Geopolitical theory has developed through reflection on the problems of state competition and, in this respect, geopolitics shares much with realist versions of international relations theory. Morgenthau $(1993,5)$ presents politics as the pursuit of 'interest in terms of power'. International politics, for him, comprehends the pursuit of self-interest by states in competition with other states, in a context where there is no overall constraining structure. Unlike domestic politics, then, shaped by national law and legitimacy, international politics is an anarchic world devoid of consensual and enforceable law. For realists, international relations theory need address little beyond how and with what consequences states use force against each other.

Realists sometimes acknowledge that this is a bleak view of the world. Mearsheimer (2001), for example, writes of The Tragedy of Great Power Politics. Recalling Thatcher's claim that 'there is no alternative' (TINA) to capitalism (Bateman 2002), there is a strong whiff of TINA about this perspective. This view of the world promises to naturalise the gross power inequalities and exploitation of imperialism (Kearns 2006). In this sense, 
we might, I think, speak of this common ground between realist international relations and traditional geopolitics, as a form of conservative geopolitics. In other words, these approaches accept, with more or less regret, the unfairness of the world as it presents itself and conceive no way to imagine it shaped more equitably. On this perspective, the best that can be expected is that the global hegemon should for its own whimsical reasons choose to use its force to impose freedom.

There are theoretical and practical ways that we might try to develop a progressive geopolitics. The first would be through a critique of existing theory and the other would be by redirecting our attention towards neglected practices, and critical geopolitics is now well established at least in the first of these respects. Its focus has been discourse, 'problematizing the production and use of [geopolitical] knowledge in various orders of power and space' (Dalby and Ó Tuathail 1996, 451). Discourse, of course, is much broader than texts (Müller 2008) and includes those institutions through which particular ways of conceptualising the world produce their effects. Ó Tuathail $(1994,526)$ insists that critical geopolitics 'is problematizing how geographical discourse and systems of power work through each other to project maps of global politics with familiar centers and foreign peripheries, core identities and marginal spaces, tame regions and wild zones.' Nevertheless, and despite reference to the importance of geopolitical 'sites' (Ó Tuathail 1994, 536), much of this work is in fact about texts. In the main, this work has drawn attention to the tropes of geopolitical arguments, both to undermine the self-evidential way that these metaphors and framings sustain geopolitical projects that should be contested, and to deconstruct the tropes themselves by showing that they can never bear the weight placed on them. The majority of writings on critical geopolitics concern the discourses produced by, about, or for, the most powerful agents in the geopolitical world order (though, see Dalby 1999).

There are certainly works of progressive geopolitics that move beyond texts and imagery, and describe explicitly the violence of states. Indeed, it is in linking states and violence that some of the most critical work in geopolitics has been produced. Gregory's (2004) work on violence within Iraq, Afghanistan and Israel/Palestine is exemplary (see also Gregory and Pred 2007). Oslender (2004) has likewise studied the violence visited on black communities of Colombia's Pacific coast and in his study of the resistance of this social movement he has noted that an indigenous sense of place in terms of an 'aquatic space' is at the heart of their organising against the hegemonic scale of the state. Nevins (2003), in rejecting understandings of the state that treat it only in terms of the logic of capital accumulation (Purcell and Nevins 2005), highlights instead the structural violence that most forms of nation-building exclude from their commitment to truth and reconciliation. This is only a sampling of a rich literature in what, following Benhabib (1986), we might term the moment of critique. I think that this critical work is vital but I think that it needs to be 
supplemented by the further, utopian moment of progressive geopolitics. In other words, we need to be attentive to the possibilities of progressive change and that is not best achieved by contemplating only the constraints of the present; in this case, the violent relations between states.

There are indeed more things than are dreamt of in the philosophy of either conservative geopolitics or the realist theory of international relations. In simple terms, there are more things than states and there are more relations than those of force. Furthermore, this is where may be found some of the progressive possibilities of the present, non-states and nonviolence play a significant role in shaping the modern world order. This has been understood within feminist critiques of geopolitics, as when Gilmartin and Kofman (2004, 122) bemoan the "non-gendering of geopolitics' and highlight the exclusive emphasis of geopolitics on state elites. In a review of the relations between feminism and geopolitics, Hyndman $(2004,308)$ identifies the same statecentrism, suggesting that '[w] hile the state remains a vital subject of interrogation in relation to security, it obscures fear and violence at other scales beyond its purview.' There is already a critique of state-centrism in political geography from scholars developing Wallerstein's world-systems perspective (Taylor 2000). Various theorists of globalisation have likewise suggested that the significance of the state and the state system is today somewhat reduced (Brenner 1999; Falk 1997). I am reluctant to reduce this to a question of scale, and want instead to think about some of the agents other than states, and agencies other than violence that matter, without placing the state as a stable scale between local and global. In other words, the agents I am interested in operate in a series of contexts both above and below the state. Elsewhere (Kearns forthcoming, Chapter 9) I attempt a sketch of the political economy with which these agents and agencies engage, but I hope it is clear in what follows that the agents with which I deal deploy political and economic power consubstantially. Similarly, the agencies of non-violence, solidarity and justice that are described here always run up not only against the explicit violence of state and other agents that pursue the interests of the rich and powerful, but also against the implicit structural violence of an inequality that renders too many livelihoods vulnerable while leaving too few living in ease (for a discussion of the 'vital' perspective, see Kearns and Reid-Henry forthcoming).

\section{States and Non-States}

TRANSNATIONAL CORPORATIONS

There are a range of non-state entities that matter in global geopolitics. At the very least, we must acknowledge transnational corporations (TNC), non-governmental organisations (NGO), regional alliances of states, and multilateral agencies. Part of the difficulty with geopolitics, at 
least insofar as it relates to human geography, is that topics that are treated in economic terms are not often also treated in political terms. For example, there is a great deal of work on the dialectic between the local and global in the economic practices and impacts of TNCs. Geographers have made important contributions to the debate about globalisation, considering such questions as whether firms are still nationally rooted in any significant manner (Dicken 2003)? There is also a good deal of work on whether under pressure of globalisation, states are losing control over their national economies, leading some to write of an Unruly World (Herod et al. 1998), a global economic system no longer ordered tightly by a network of states. I am not persuaded that globalisation is a useful way to conceptualise the agency of TNCs. In the first place, TNCs are not new and yet globalisation is presented as a novelty. Theorists too easily hypostasise the supposed intensification of international capital mobility as a process in its own right independently of the agency of TNCs. In this way, 'globalisation', itself, as Agnew and Corbridge (1995) point out, serves the ideological function of sustaining neoliberal economic choices by allowing theorists to argue that in this newly globalised world, choices that were available to states in former times are no longer on the table.

There is a need to theorise the agency of TNCs more explicitly. For example, Ietto-Gillies (2002a) offers a helpful sketch of the decisions behind the location decisions of TNCs. Thus, TNCs must decide between, on one hand, exporting goods produced at home and, on the other hand, both producing and selling in overseas markets. In making this choice, they may be influenced by state or multistate regulatory regimes (notably tariffs) that would favour production abroad and also by the use of foreign production as a learning strategy, tapping into foreign technology and management systems. TNCs must also choose between including all stages within their own company in comparison to outsourcing some stages to other companies, again either at home or abroad. Finally, TNCs must choose whether to invest in many countries or only in a few. Ietto-Gillies goes on to suggest that the spread of cross-border activity within companies has been influenced both by the increasing financialisation of economic activity and by the development of new information and communications technologies. The first makes investment less stable and the second makes the integration of activity across space more straightforward. Together, they produce an intensification of the frequency and volume of flows of foreign direct investment. This research agenda, though, is rather difficult to operationalise. When it comes to the empirical study of firms, Ietto-Gillies (2002b) relies on two indices: an index of internationalisation (the number of a company's affiliates and subsidiaries that are located abroad divided by the number located at home) and an index of network spread (the number of countries in which subsidiaries are located divided by the number of foreign countries accepting foreign direct investment). For five dates in the period 1963-1997, Ietto-Gillies calculates these 
indices for the UK companies that are among the world's top 500 manufacturing or mining companies. The agency of TNCs is described but not observed in such an analysis.

Even in these abstract terms, this is, from a geopolitical perspective, a rather narrow understanding of the agency of TNCs, particularly when it comes to such powerful players as the largest extractive and manufacturing companies. The explicit separation of political context from economic decision is unrealistic. The largest companies have repeatedly acted in directly political fashion. There has been, and continues to be, a close relation between national foreign policy and the promotion of national businesses. In the case of the oil companies, for example, British policy in the countries of the Persian Gulf and the Caspian Basin has been supportive to the extent of direct collusion. Thus, the territorial arrangements imposed on the ruins of the Ottoman Empire after World War I were organised around securing Anglo-Persian a monopoly in the oilfields of Persia (Sluglett 1976). The British government had purchased 51\% of this company at the start of the war. Yergin (1991) shows the similar ways that the overseas interests of Standard Oil were promoted by the US government. The process continues today, of course, with countries such as the USA, China, Russia, France and Britain all competing to secure drilling concessions for their own national oil companies in both these well-established oilfields (Kleveman 2003) and in other places such as Sudan and Nigeria. So important are these resource wars (Klare 2001) that it is in this context that the term geopolitics came back into common use after the avoidance of the term in the decades following the Nazi appropriation of the term (Kearns forthcoming).

These close associations are clear not only in the case of oil. In 1954, the military intervention in Guatemala by the USA was prompted by the nationalisation, with compensation, of a US company, United Fruit (Schlesinger and Kinzer 1982). The privatisation of natural resources that Harvey (2003) has termed accumulation by dispossession, may have been imposed on many countries as part of structural adjustment policies, but it was particular companies, such as Rio Tinto Zinc (Moody 1996), that cultivated the political links to leave them well placed to buy these resources. In other words, it is by acting politically that companies pursue economic opportunity, by being an integral part of international relations that they act economically. My point is that this dimension of geopolitics can only be understood by theorising the conjoint agency of governments and TNCs. TNCs extend the agency of states, and vice versa (Hirst 2005).

In other words, the agency of TNCs must include their cooperation with governments. At one level, this is revealed by lobbying and campaign financing. In the US 2001-2 electoral cycle, the 86 largest US companies accounted for about $5 \%$ of all electoral contributions that passed through political action committees (Anderson and Cavanagh 2004, 7; Center for Responsive Politics 2007). The US government now incorporates ever 
more directly the largest corporations into the negotiation of trade agreements. Beyond this, there is, in the USA, such a privatisation of government activities that Klein (2007) speaks of extensive corporatism. Taxes are raised publicly but they are spent, increasingly, not through agencies that are part of government, but by commissioning services from private companies, in fields as diverse as education and the military. This corporatism is an important aspect of geopolitics. States act, in part, through, with, and on behalf of TNCs. TNCs are political and not just economic agents.

In very important ways, then, TNCs can be agents of imperialism. In this respect, understanding their agency contributes to an understanding of how global inequities are reproduced. There is, however, another side to the operation of TNCs that might attract the attention of people wishing to theorise the prospects for a fairer world. Because TNCs do business in many countries, legal and consumer pressure in one place can be used to address the responsibilities of the company towards people in another. For example, revived for use in the 1980s was an Alien Tort Claims Act passed by the very first US Congress in 1789. This "provides federal courts with jurisdiction over violations of the "law of nations", (Collingworth 2003, 1). If corporations can be shown to have knowingly employed people under conditions of slavery, or where torture, murder or rape are used as forms of labour discipline, then, they are complicit in those actions. In 1992, Unocal and Total, a US and a French oil company, engaged with the government of Burma to have a natural gas pipeline built for them. Despite warnings about the nature of labour relations under the Burmese junta, the companies went ahead. Unocal and Total employed the Burmese army as their security services on the project, which was completed in 1998. Workers were kidnapped from villages, and where workers were recaptured after escape they were tortured, as a warning to others. Both the International Labor Rights Fund and the Center for Constitution Rights took up the case of Burmese villagers in US courts, first in California, and then, invoking the parallel with the prosecution of companies that knowingly benefited from subsidiaries that employed slave labour in Nazi Germany, the case was remanded to federal district court for trial. In 2005, Unocal settled out of court (Rosencranz and Louk 2005).

The transnational nature of these companies can be a way of making them a vehicle for mitigating the imperialist purpose they more generally serve. It is true, as Jochnick (1999) notes, that it is difficult for poor countries to regulate TNCs, which exceed in annual earnings the gross domestic product of many such countries. Chesterman (2004) is likewise sceptical about the prospects for using the national law of the home country of the TNC to prosecute for human rights abuses committed abroad. Chesterman cites the case of ExxonMobil's activities in Aceh, Indonesia, where the US State Department prevented a case proceeding through the US courts because US interests might be harmed; Indonesia 
being, in 2002, an ally in the Global War on Terror. In this sense, Burma's military junta stand isolated as a pariah state, and this means that they get no help of this kind. Chesterman sees more potential in voluntary codes of conduct such as the Global Compact, initiated by the Union Nations (UN) in 1999. Because, in any case, international law exists largely as a consensual system, the use of codes and compacts to embarrass TNCs is perhaps as good way as any to develop international compliance. This means that when it comes to regulating human rights aspects of TNC operations, the state 'is increasingly supplanted by sub-state and supra-state normative regimes' (Engle 2004, 106). O'Rourke (2003, 3) argues that NGO regulation of TNC labour practices 'can be effective [...] when monitoring and remediation are technically rigorous, publicly transparent, politically legitimate, and accountable to key stakeholders (in particular to workers and consumers).' Explicitly rejecting TINA, Ruggie (2002, 28) suggests that there will be a backlash against globalisation unless it can cultivate 'popular roots and social legitimacy', and that this requires that TNCs should be able to label themselves as responsible producers and ethical employers (Diller 1999).

In this respect, it is, of course, only public pressure and exposure that will counter the irresponsibility that is the very purpose of outsourcing. Recently, the demonstration that child labour was impressed by one of its subsidiaries produced this concession:

Gap said it was unaware that clothing intended for the Christmas market had been improperly subcontracted to a sweatshop using child labour. It announced it had withdrawn the garments involved while it investigated breaches of the ethical code imposed by it three years ago. (McDougall 2007)

Such ethical codes result from the public finding it unacceptable that conditions of work should be set solely by the market and recall Marx's (1993 [1864], 79) endorsement of the British Ten Hours' Act (1847) as 'the victory of a principle; it was the first time that in broad daylight the political economy of the middle class succumbed to the political economy of the working class.' The bourgeois belief in 'the blind rule of [...] supply and demand' now met the working class advocacy of 'social production controlled by social foresight'. It might be depressing that the 19th-century struggles over working conditions return on a global scale but regulation, inspection and moral pressure remain forces for progressive change in countering slavery (Bales 2005), child labour (Seabrook 2001), and unsafe workplaces (International Labour Office 2007). Geographers show a growing, and critical, engagement with these issues (Barnett et al. 2005; Hale and Opondo 2005; Hughes 2001; Klooster 2006; Malpass et al. 2007; Sadler 2004). It is evident from these and other studies that there is progressive potential in regulating TNCs and that this potential is more easily realised where there is: monitoring by NGOs, the formulation of international law, and solidaristic pressure for change. 
There is, again, relatively little work in geography on the geopolitical significance of NGOs. There have been some studies of their promotion of economic, social and political development in poorer countries (Mcllwaine 1998; Mercer 2002). Sundberg (1998) writes of the transformation of society by NGOs, in both intended and unintended ways, as the creation of NGO landscapes. Others have questioned the extent to which NGO activity regulates rather than empowers the poor (Townsend et al. 2002). Although Mohan (2002) is right to stress the transnational nature of many NGOs (which is why they are relevant to the study of global geopolitics), it remains the case that they usually recruit their senior staff and declare their profits in some home countries. In many ways, they replicate the questions raised by studies of the effects of globalisation on TNCs. NGOs likewise operate by forming relations with various states and with various other multilateral institutions. However, in seeking to understand the agency of NGOs, we are helped by the fact that they are good deal more open about what they do than are TNCs.

In a very useful review of development NGOs, Bebbington (2004) stresses their network nature. NGOs connect people in different places. This can have consequences, either economically, in introducing rural producers to new 'fair trade' international markets, or politically, in deploying international solidarity to draw attention to unjust conditions in particular localities, as is the regular achievement of Amnesty International. Indeed, it is difficult to underestimate the significance of Amnesty International (Clark 2001) and Human Rights Watch in cultivating a more general sensibility about international human rights through their campaigns on behalf of those abused by torture or unfair imprisonment. Taylor $(2004,270)$ maps NGO activity to show that, rather than replicating the 'Western' bias of their headquarters, NGO activity is concentrated in sub-Saharan Africa, and, in this way, 'their global activities are providing a legitimising platform for dissident and diverse voices from regions where economic and political power is lacking.' McFarlane (2006) identifies the agency of NGOs in shaping new, and more egalitarian, learning networks whereby understandings of globalisation no longer flow down from the Western academy to the Third World activist. A similar point about new geographies of knowledge is made by Slater (2004), although the place of NGOs in this amplification of local knowledge is not Slater's primary concern.

Non-governmental organisations have a complex relationship with sovereign states. Some NGOs, such as the International Red Cross/Crescent, operate only with the explicit permission of the states claiming jurisdiction over the territory in question. Others, notably Médecins Sans Frontières, recognise that in some circumstances states will deliberately deny international aid access to parts of their country and thus to some of their subjects, particularly if the regions are involved in civil war. Debrix (1998) writes 
of a 'new geography of international medical assistance' that builds networks under the exclusionary barriers of state sovereignty. In fact, however, Médecins Sans Frontières has found it very difficult to operate with safety in places where states forbid their presence and, with regard mainly to the safety of its local staff, has withdrawn from most states where its access is restricted by official decree (Redfield 2005, 2006; Terry 2002). Nevertheless, NGOs have been at the heart of debates over humanitarian intervention of various kinds and Smith $(1998,76)$ suggests that 'a state that is oppressive and violates the autonomy and integrity of its subjects forfeits its moral claim to full sovereignty.'

\section{MULTILATERAL AGENCIES}

With the end of the Cold War, the UN seized the opportunity to discard the paralysis of not being able to involve itself in most parts of the world, claimed as clients by one of the two great powers (Traub 2006, 22). The principles of this renewed assertiveness on the part of the UN were human rights and global solidarity. Wheeler (2000, 12-13) suggests that this new position of humanitarian intervention acknowledged the contingency of sovereignty with human rights abuses 'morally entitling other states to use force to stop the oppression.' Wheeler argues that the moral authority of the UN means that states now try to justify their use of force in terms of these human rights norms and that this places restrictions on what they can do, even if it does not restrain them as fully as the norms would imply.

There are very many problems with this strategy of forceful humanitarian intervention. Very often, the UN does not have the troops to intervene with skill and efficiency. In one of the few geographical studies of peacekeeping, Grundy-Warr (1994) concluded that peacekeeping would only work where the UN had the support of both parties in any civil war. This is perhaps a too despairing counsel. The refusal to take sides where crimes against humanity are involved produces an incapacity that hides behind neutrality, as in the failures in Bosnia, where, in fact, the British used the danger to their own troops in the UN peacekeeping force to defer the combination of air strikes and military support for Croats and Muslims that eventually stalled the project to create Greater Serbia (Simms 2001). Given the reluctance of contributing nations to put the troops they send peacekeeping in any sort of danger, attacking peacekeepers becomes, not a trigger for forceful retribution, but merely a way of clearing the field for more extensive violence, as happened in Rwanda in 1994, where the withdrawal of peacekeepers after the murders of Belgian soldiers, gave Hutu militias free-run to murder 800,000 Tutsis in about 100 days (Traub 2006, 51).

In the middle of the Cold War, it was likely that such civil conflicts would be limited as a consequence of the affiliation of the warring parties 
with rival great powers and thus the dangers of strife escalating to global confrontation. The UN, at that time, was only able to act in those few instances where super-power interests were not in play because if they were a Security Council veto by one or other side was always sufficient to scotch intervention (Urquhart 2007). Rupert Smith $(2005,17)$ argues that it is time to recognise that the old model of what he terms 'industrial war' between states has been supplanted by what he terms 'war among the people'. In this new species of conflict, non-state coalitions fight not in order to prevail but in order to create conditions under which a new political arrangement can be negotiated. Modern war is rarely fought through to conclusive victory because, argues Smith (2005, 358), these non-state coalitions fight in such a way as to 'conserve the force'. The increasing privatisation of the US military, with the use of mercenaries (Scahill 2007) and of military service as expediting immigration (Bender 2006; Meyer 2007), might reduce the political cost of military casualties, although the economic cost of training and equipping either mercenaries or foreign legions remains high.

This recent development of military humanitarian intervention has clearly changed the relations between force and states, and between states and multilateral institutions such as the UN and the North Atlantic Treaty Organisation. Since the end of the Cold War, there has been a fairly steady decline in global violence (Gurr 2000; Harbom and Wallensteen 2005; Marshall and Goldstone 2007). The Human Security Centre (2005, 1) reports that '[b]etween 1991 [...] and 2004, 28 armed struggles for self-determination started or restarted, while 43 were contained or ended. There were just 25 armed secessionist conflicts under way in 2004, the lowest number since 1976.' The report concludes that ' $[w] i t h$ the Security Council no longer paralysed by Cold War politics, the UN spearheaded a veritable explosion of conflict prevention, peacemaking and post-conflict peace-building activities in the early 1990s' (Human Security Centre $2005,8)$. The major exception to this trend has been the persistent increase in what Marshall and Goldstone $(2007,5)$ term 'high casualty terrorist bombings' (HCBTs; at least 15 deaths). From 11 September 2001 to 25 February 2007, there were 15,614 such deaths including the 2982 who died in the USA from the attacks of 11 September 2001. There are six 'high incidence states'. The USA has had no further HCBTs after 9/11. Afghanistan (243 deaths), Israel (348), Pakistan (583) and Russia (1428) saw initial increases after $9 / 11$ but by 2004 the only country with substantial and persistent HCBTs was Iraq (6650 deaths). By 2004, the civil war/insurgency in Iraq was the only example of international involvement in an internal conflict (Harbom and Wallensteen 2005, 629).

During the Cold War, multilateral institutions were more wary of state sovereignty than they have since become. Another clear example of this is the World Trade Organisation (WTO). Developing out of the international agreements that promoted freer trade between states, the WTO now seeks 
to intervene more explicitly in the internal regulatory affairs of states. No longer content to reduce tariffs, at least for those states too weak to defy it, the WTO insists that states accept a common regulatory regime because all beyond this bare minimum is branded as 'in restraint of trade' (Wallach et al. 2004). In other words, it is no longer acceptable that a state should treat imported goods and domestic goods in an even-handed manner, and they must now treat all according to the standards that the WTO presents as universal. The WTO now beats down not only tariff barriers but also domestic regulatory intent in a manner that seriously compromises state sovereignty. My argument, then, is that NGOs and multilateral institutions are increasingly effective agents in inter-state relations. The former in many cases have the potential to enhance state capacities, while the latter are at risk of becoming little more than agents of Western imperialism. Indeed, the WTO is so unfair that most poorer countries would perhaps best serve their interests by derogating from its regulations.

Alongside the increased activity of transnational agencies of various kinds, there have developed transnational social movements. These are seen by some commentators as promising a new kind of global civil society (Wapner 1996). This new non-state political identity is produced more readily in those states that themselves respect international obligations because residents of '[c] ountries with structured, routine participation in the global polity - measured in terms of memberships in international organizations and treaties - are more likely to become "socialized" into the norms of international society' (Smith and Wiest 2005, 637).

\section{Force and Non-Force}

\section{NON-VIOLENCE}

Geography's feet are caked with clay from the battlefield. Friedrich Ratzel's observation of 1897 that '[w]ar is the school of space' (Mendieta 2006, 208) registers that the territoriality of war both draws on and stimulates geographical research. The Franco-Prussian War (1870) was widely seen as a triumph of German geographical training and was repeatedly invoked when people promoted geographical education in late 19th-century Britain. Indeed, the New Geography of Mackinder and his allies was promoted in and through the British military (Hudson 1977; Stoddart 1992). After World War II, Eva Taylor (1948, 137) celebrated the 'sudden rise of geographical prestige which occurs in war time.' Around the end of the war, there were many studies, such as Spykman's (1944) The Geography of the Peace, on what one reviewer termed the 'wearisome frontier problems of Europe' (Steers 1948, 431; see, among many others, Dixon 1946; Peattie 1944; Van Valkenburg 1946). Spykman (1942, 436) believed that the necessity for borders arose from the 'great inequalities in military strength between states' and Gottman (1951, 172) was sure that secure borders 
were needed by states because '[s]overeignty may well be the legal tool through which people attempt to preserve their right to differentiate themselves from their neighbors.' The units are assumed to be states (based on distinctive peoples) and their mutual relations are assumed to be hostile, unless corralled by effective boundaries. These themes continue to characterise much political geography (among many others, Corson and Minghi 1996; Newman 1996; van der Wusten and O'Loughlin 1986). A major stimulus to the development of geographical information systems has also been its military applications (Corson and Palka 2004; Roberts and Schein 1995; Smith 1992). Lacoste (1976) famously asserted that geography has been, primarily, about making war. Geographers, like Robert Frost's (2002 [1914], 1. 27) neighbour, seem to believe that ' $\mathrm{g}$ ] good neighbors.' Perhaps, like Frost $(2002,1$. 1) with his neighbour, we might yet try to insinuate among the geographers the notion that '[s]omething there is that doesn't love a wall.'

If we never study anything but sovereign states we will never imagine, or understand, the circumstances under which sovereign states might choose to pool sovereignty, to attempt the 'mischief' (Frost 2002, 1. 28) of letting walls fall to ruin. If we never study anything but force, its emergence and containment, we will never imagine, or understand, how to make peace in other ways; through pooling sovereignty (Duedney 2000) or pursuing justice (Dower 2002). We will be forced to accept O'Loughlin and van der Wusten's $(1986,501)$ counsel of despair and focus on war and the 'absence of war, or negative peace'. In his prospectus for political geography, O'Loughlin (1986) treats international relations solely in terms of war and conflict. Pepper and Jenkins (1983), in an unfortunately named peace manifesto, 'A Call to Arms', proposed a series of geographical research topics as a contribution to peace studies, and all were about understanding war. The emphasis of their edited collection, The Geography of Peace and War, is 'on war rather than direct peace studies' (Pepper 1985, $3)$. Indeed, each of three collections about the geography of war and peace focuses in the main on war (Flint 2005a; Kliot and Waterman 1991; Pepper and Jenkins 1985). Not many have taken up the challenges thrown down by Bunge (1973) and Wisner (1986). There have been a few works on the geography of peace movements (Brunn 1985; Miller 2000; Pickerill and Webster 2006; Routledge 2003). There are also a few geographical studies of structural violence (Galtung 1969, 1996) as it imperils peace (McIlwaine 1999; Mustafa 2005; Watts 1983).

Force is tamed, not primarily by an equivalent counter-force, but by justice, legality and negotiation. Violence is a refusal to listen and it is thus inimical to truth. Cortright (2006) presents non-violent social action as a striving for truth. Vaclav Havel in communist Czechoslovakia emphasised the importance of establishing alternative institutions allowing people to live in truth (Schell 2003). In On Violence, Hannah Arendt (1969) drew a distinction between violence and power that helps explain why non-violence 
can be so effective. Arendt notes that power comes from people acting together and such cooperation will best be secured by consent. The trust that allows cooperation is legitimated by a sense that society is fundamentally just and is poisoned by flagrant injustice. Kurlansky (2006) documents the power of non-violence in a range of contexts from religious to independence struggles. George (2004) insists that the anti-globalisation struggle has been effective precisely where it has imposed the discipline of nonviolence on its members. Fry (2007) reminds us that war is a recent development in human history, dating back only to the invention of agriculture and the emergence of states:

[A]n overemphasis on violence, including warfare, by the dark-sided, demonic school of thought ignores and obscures how humans manage to live peacefully together most of the time. A more realistic perspective also takes into account restraints against violence, aggression prevention activities, non-violent conflict management techniques, and reconciliation strategies that humans regularly practice. (Fry 2007, 89)

Rather than being an unavoidable, pervasive and dominant aspect of international relations, force has been subject to significant check at various times. Peace has been made more often than war. The statist perspective and the obsession with force reinforce each other. Countering one undermines the other. Coercion is less effective than cooperation, although it often appears to offer a quicker solution. To build a just new world order, we need to develop and respect international law.

\section{INTERNATIONAL LAW}

There is now a broad literature on legal geography (Blomley 1994; Blomley et al. 2001; Holder and Harrison 2003). Very little of this literature considers international law or takes up Hyndman's $(2000,1)$ observation that international ' $[\mathrm{b}]$ orders breed uneven geographies of power and status' (but see, Buchanan 2001; Carmalt 2007). There are two principal bases for international human rights arguments. In the first place, we might invoke norms that are necessarily implied by the very existence of a social order (Moon 2003). The Kantian categorical imperative grounds morality in universal principles, which must hold, then, at all scales and it is on this basis that Habermas calls for a global commitment to republican principles. In the second place, we can acknowledge that by cooperating with others we are more productive than we would be without their assistance. On this basis, Hume suggested that we must share the benefits of cooperation with all those who lend their assistance. For this reason, Rawls argues that global justice implies not only political rights but also fairness in the distribution of wealth. There are clearly relations between these so-called (Vašák 1977) first-generation (civil and political) and so-called second-generation (social and economic) rights. In some 
circumstances, formal rights are difficult to claim, fail to become substantive because people lack the resources to access the legal system. Nevertheless, it is true that, insofar as we can talk about effective international human rights, the negative rights of being free from unjust violence are more widely accepted than the positive rights of a just share in global wealth.

From a statist perspective, absent a global-state, international law is an oxymoron (Nagel 2005). Realist theories of international relations insist that the global system is anarchic because it necessarily lacks a central regulating authority (Mearsheimer 2001, 30). Yet, there are three ways that international law can be said to be meaningful. In the first place, states may choose to incorporate international regulations into national law. It might appear that this is volitional and that the international dimension has little independent force. However, institutions like the European Court of Human Rights often lead national opinion. The Court is a forum somewhat more detached from national public opinion than are national parliaments. In this calmer place, judgements are made that the 47 signatory states agree to respect even if it means changing national law (Moravcsik 2002). There are some disappointing derogations (as with UK's insistence on being allowed to hold persons for 28, rather than four, days before bringing them before a judge to be charged). Nevertheless, the Court has given human rights a more effective voice across the continent of Europe. Such transnational institutions often give standing to more than just states. Not only may individuals bypass their state and appeal directly, but NGOs can also make representations. In this respect, these 'settings are the focus of a transnational politics of movements and organizations, and not only an intergovernmental politics between states' (Cohen and Sabel 2006, 165). The transnational exists, then, not only as a legal space but also as one that incorporates more than mere sets of states.

The second way that international law can be said to be effective is where the community of states acts in accordance with its existence. Robertson (2006, 95-96) sets outs three stages in the establishment of an international human right. There are rights that governments feel obliged to claim that they respect (opinio juris). As these rights become part of the accepted rules of the community of states, no state is able to exempt itself (jus cogens). Finally, such rights are so well recognised that each state owes it to all other states to bring to justice violators of these rights that appear within their jurisdiction, regardless of whether the crime was committed there or somewhere else (erga omnes). There are, then, two ways such international laws can be effective. In the first place, a national court may hear a case against someone who has committed crimes against humanity. In this connection, the House of Lords agreed in October 1998 that Pinochet could be extradited to Spain because a Spanish court had issued a warrant against him for directing a systematic campaign of torture in Chile. In the second place, the UN can set up ad hoc tribunals to prosecute individuals for systematic (usually state-sanctioned) policies of genocide, 
torture or war crimes. Two places, where the UN peacekeeping efforts were catastrophic failures, have subsequently seen the creation of courts of justice with the International Criminal Tribunal for the Former Yugoslavia (ICTY; from 1993) and the International Criminal Tribunal for Rwanda (ICTR; from 1994). In each, significant numbers of commanders and politicians have been indicted for atrocities. Robertson (2006) concludes of the ICTY that 'its achievement in processing and punishing most of the persons responsible for commanding atrocities in the Balkans has been considerable' (p. 405), and of the ICTR that it has 'functioned in Africa to end the impunity of genocidal heavyweights - eleven government ministers and a swag of generals and colonels who would otherwise have gone unpunished' (p. 409).

The third way that international law can function is as a source of paradigmatic jurisprudence. International human rights has been characterised as placing individual rights above state rights. It is clear that a further development has been to place group rights above the force majeure of majoritarian democracy (Elster 1993). This development is perhaps largely responsible for the decline in ethnic violence over the past two decades. Based on a study of 300 'politically active ethnic and religious groups' over the second half of the 20th century, Gurr $(2000,53)$ identifies the 1990s as remarkably quiescent: '[b]y the late 1990s, the most common strategy among ethnic groups was not armed conflict but prosaic politics.' From the early 1990s, European jurisprudence, as expressed through the Organisation for Security and Cooperation in Europe and the Council of Europe, shifted towards a greater concern with group aspects of human rights, particularly those relating to national minorities. Models for respecting minority rights were thus available for the new democracies of Eastern Europe. These examples also offered as an alternative to complete independence, realistic templates of regional autonomy to ethnic nationalist movements outside Europe. The benefits of accommodation are thus made clearer to both sides in civil war.

International law, then, can be effective. It can change the expectations of the brutal men who might once have anticipated realpolitik to ensure their impunity. In 1996, Ieng Sary, the Foreign Minister for the Khmer Rouge regime, defected from the rump of the Khmer Rouge still fighting the democratic government in Cambodia. For this cooperation, he was rewarded with a royal pardon for any past crimes. In 1997, the Cambodian government asked for UN assistance in bringing to justice the Khmer Rouge criminals. Finally, in the summer of 2007, the tribunal began issuing warrants to arrest those it wished to try. Setting aside earlier amnesties as inadequate defence against charges of crimes against humanity, the tribunal issued and executed a warrant for the arrest of Ieng Sary on 12 November 2007.

In 1954, speaking to leading American politicians, Churchill popularised the aphorism: 'to jaw jaw is always better than to war war' (Weidhorn 
1997, 47). At age 80, he was a late learner, yet he was right in 1954, and he would be right today, too. The current government of the USA has acted as if diplomacy were a sign of weakness. In December 2003, the US Vice President, Richard Cheney, allegedly aborted the six-nation anti-nuclear discussions with North Korea by insisting to senior American State Department negotiators who were considering a Chinese draft agreement: 'we don't negotiate with evil; we defeat it' (McDonald 2003). Yet, mired in Iraq, US threats against countries acquiring nuclear weapons capabilities sound hollow. Force did not prevail. In October 2006, North Korea claimed to have completed an underground nuclear weapons test. Within a week, the UN Security Council imposed sanctions. In January 2007, the six-nation negotiations began again in Beijing. In February, a draft agreement was reached, and in April the USA released North Korean funds frozen in a US bank. The six-nation agreement was signed at the end of September 2007 (Cable News Network 2007). It took nearly 4 years to get back to what Cheney had thrown away. The US gains in moral authority to the extent that it pursues multilateral agreements and can show that its actions reinforce global human rights. Far from force being the only effective power in global relations, it is easily bankrupted in the absence of the sort of 'soft power' (Nye 2004) best cultivated through good example and international institutions.

\section{Conclusion}

In a very insightful review, Mamadouh (1998) has written of neoclassical geopolitics with its geo-strategic emphasis on the national security interests of distinct and hostile states. Realist international relations theory is almost identical. Both sets of writers strike a tragic pose, regretting the geostrategies of force they must perforce propose for a world that can exist in no other fashion. They naturalise international anarchy. Mamadouh (1998, 242) recognises that the same statism is taken up by many writers claiming, rather, to be critical of geopolitics, producing discourses of ' $[\mathrm{n}] \mathrm{on}$ geopolitics [...] the study of the spatial distribution of power between states'. Ó Tuathail $(1987,197)$ identifies the failure of imagination produced by non-geopolitics' naive and empiricist treatment of the state system: 'the state is normalized as a natural unit of political organization with identifiable interests and objectives (raison d'etat).' One way of developing beyond classical geopolitics (the 19th-century Social Darwinists), neoclassical geopolitics and non-geopolitics, is, as Mamadouh argues, to take up the deconstructive work that Ó Tuathail (1996) has developed as critical geopolitics. A series of scholars have highlighted the political assumptions structuring the concepts of almost all geopolitical writings. Flint (2005b, 5) registers a certain frustration when he offers his recent edited collection as 'not another example of critical geopolitics', of deconstruction, but rather as a set of 'constructions of theoretically derived geographies that 
explain war to complement critical geopolitics that deconstruct discourses'. Flint identifies some of the themes I raise. He writes of avoiding the 'territorial trap of considering sovereign states as the only political territory worthy of investigation' (Flint 2005b, 6) and he notes that peace is 'not only the absence of war, but also the possibility of maximizing human potential' (Flint 2005b, 7). His own article on the 'Dynamic metageographies of terrorism' (Flint 2005c) tries to problematise the relations between terrorists and states before concluding that states 'frame both the actions and the goals of religious terrorists' whereas he says nothing at all about 'human potential'. We need, I think, to think systematically outside the framework of realist international relations, of classical, neoclassical and non-geopolitics, if we are to capitalise on the potential insights of critical geopolitics. This article suggests that if we try to do this in a systematic manner we can identify a range of non-force relations and of non-states on which we need to turn our attention. We should not remain enchained to bellicose statism, even critically. There is a more peaceful world to win.

\section{Short Biography}

Gerry Kearns is professor in Government and International Affairs, and is director of the School of Public and International Affairs at Virginia Tech. $\mathrm{He}$ has an undergraduate degree and a $\mathrm{PhD}$ in Geography from the University of Cambridge where he was lecturing for the past 13 years. He writes on historical aspects of political and medical geography and has just completed Geopolitics and Empire: The Legacy of Mackinder, in press with Oxford University Press. The argument of the current article is developed in a different manner as Chapter 9 of that book.

\section{Notes}

$\star$ Correspondence address: Gerry Kearns, School of Public and International Affairs, Virginia Tech's College of Architecture and Urban Studies, Architecture Annex (0113), Blacksburg, VA 24061, USA. E-mail: gkearns@vt.edu.

${ }^{1}$ He writes that the term geopolitics is valuable, so long as it is clearly defined, 'pour désigner les rivalités de pouvoirs sur des territoires'.

\section{References}

Agnew, J., and Corbridge, S. (1995). Mastering space: hegemony, territory, and international political economy. London: Routledge.

Anderson, S., and Cavanagh, J. (2004). The rise of corporate global power. Washington, DC: Institute for Policy Studies.

Arendt, H. (1969). On violence. New York: Harcourt Brace.

Bales, K. (2005). Understanding global slavery: a reader. Berkeley, CA: University of California Press.

Barnett, C., et al. (2005). Consuming ethics: articulating the subjects and spaces of ethical consumption. Antipode 37, pp. 23-45.

Bateman, B. W. (2002). There are many alternatives: Margaret Thatcher in the history of economic thought. Journal of the History of Economic Thought 24, pp. 307-311. 
Bebbington, A. (2004). NGOs and uneven development: geographies of development intervention. Progress in Human Geography 28, pp. 725-745.

Bender, B. (2006). Military considers recruiting foreigners: expedited citizenship would be an incentive. Boston Globe 26 December. [online]. Retrieved on 29 October 2007 from http:// www.boston.com/news/nation/articles/2006/12/26/military_considers_recruiting_foreigners/

Benhabib, S. (1986). Critique, norm, and utopia: a study of the foundations of critical theory. New York: Columbia University Press.

Blomley, N. K. (1994). Law, space, and the geographies of power. New York: Guilford Press.

Blomley, N. K., Delaney, D., and Ford, R. (eds) (2001). The legal geographies reader: law, power, and space. Oxford, UK: Blackwell.

Brenner, N. (1999). Beyond state-centrism? Space, territoriality, and geographical scale in globalization studies. Theory and Society 28, pp. 39-78.

Brunn, S. (1985). The geography of peace movements. In: Pepper, D. and Jenkins, A. (eds) The geography of peace and war. Oxford, UK: Basil Blackwell, pp. 178-191.

Buchanan, R. (2001). Border crossings: NAFTA, regulatory restructuring, and the politics of place. In: Blomley, N. K., Delaney, D. and Ford, R. (eds) The legal geographies reader: law, power, and space. Oxford, UK: Blackwell, pp. 285-297.

Bunge, W. W. (1973). The geography of human survival. Annals of the Association of American Geographers 63, pp. 275-295.

Cable News Network. (2007). Timeline: North Korea nuclear dispute. CNN.com/Asia 3 October. [online]. Retrieved on 3 November 2007 from http://www.cnn.com/2007/WORLD/ asiapcf/10/03/nkorea.timeline/index.html

Carmalt, J. C. (2007). Rights and place: using geography in human rights work. Human Rights Quarterly 29, pp. 68-85.

Center for Responsive Politics. (2007). Hard money fundraising 1987-2006. [online]. Retrieved on 9 October 2007 from http://www.opensecrets.org/bigpicture/ptytots.asp?cycle $=2004$

Chesterman, S. (2004). Oil and water: regulating the behavior of multinational corporations through law. International Law and Politics 36, pp. 307-329.

Clark, A. M. (2001). Diplomacy of conscience: amnesty International and changing human rights norms. Princeton, NJ: Princeton University Press.

Clokie, H. McD. (1944). Geopolitics-new super-science or old art? Canadian Journal of Economics and Political Science 10, pp. 492-502.

Cohen, J., and Sabel, C. (2006). Extra rempublicam nulla justitia? Philosophy and Public Affairs 34 , pp. $147-175$.

Collingworth, T. (2003). The Alien Tort Claims Act-A vital tool for preventing corporations from violating fundamental human rights. Washington, DC: International Labor Rights Fund.

Corson, M. W., and Minghi, J. (1996). The political geography of the Dayton accords. Geopolitics 1, pp. 77-92.

Corson, M. W., and Palka, E. J. (2004). Geotechnology, the U.S. military, and war. In: Brunn, S. D., Cutter, S. L. and Harrington, J. W. (eds) Geography and technology. Dordrecht, The Netherlands: Kluwer Academic Publishers, pp. 401-427

Cortright, D. (2006). Gandhi and beyond: non-violence for an age of terrorism. Boulder CO: Paradigm.

Dalby, S. (1999). Against 'globalization from above': critical geopolitics and the World Order Models Project. Environment and Planning D: Society and Space 17, pp. 181-200.

Dalby, S., and Ó Tuathail, G. (1996). The critical geopolitics constellation: problematizing fusions of geographical knowledge and power. Political Geography 15, pp. 451-456.

Debrix, F. (1998). Deterritorialised territories, borderless borders: the new geography of international medical assistance. Third World Quarterly 19, pp. 827-846.

Dicken, P. (2003). Placing firms: grounding the debate on the 'global' corporation. In: Peck, J. and Yeung, H. W.-C. (eds) Remaking the global economy: economic-geographical perspectives. London: Sage, pp. 27-44.

Diller, J. (1999). A social conscience in the global marketplace? Labour dimensions of codes of conduct, social labelling and investor initiatives. International Labour Review 138, pp. 99-129.

Dixon, M. V. (1946). The true facts about the disputed frontiers of Europe. London: Burke.

Dower, N. (2002). Against war as a response to terrorism. Philosophy and Geography 5, pp. 29-34.

Duedney, D. (2000). Geopolitics as theory: historical security materialism. European Journal of International Relations 6, pp. 77-107. 
Elster, J. (1993). On majoritarianism and rights. East European Constitutional Review 1 (3), pp. $19-24$.

Engle, E. (2004). Corporate social responsibility (CSR): market-based remedies for international human rights violations? Willamette Law Review 40, pp. 103-121.

Falk, R. (1997). State of siege: will globalization win out? International Affairs 73, pp. 123-136.

Flint, C. (ed.) (2005a). The geography of war and peace: from death camps to diplomats. Oxford, UK: Oxford University Press.

- (2005b). Introduction. In: Flint, C. (ed.) The geography of war and peace: from death camps to diplomats. Oxford, UK: Oxford University Press, pp. 3-15.

- (2005c). Dynamic metageographies of terrorism: the spatial challenges of religious terrorism and the 'war on terrorism.' In: Flint, C. (ed.) The geography of war and peace: from death camps to diplomats. Oxford, UK: Oxford University Press, pp. 198-216.

Frost, R. (2002 [1914]). Mending wall. In: idem (ed.) The poetry of Robert Frost. New York: Henry Holt, p. 33.

Fry, D. (2007). Beyond war: the human potential for peace. Oxford, UK: Oxford University Press. Galtung, J. (1969). Violence, peace and peace research. Journal of Peace Research 6, pp. 167-191.

-. (1996). Peace by peaceful means: peace and conflict, development and civilization. London: Sage.

George, S. (2004). Another world is possible if . . London: Verso.

Gilmartin, M., and Kofman, E. (2004). Critically feminist geopolitics. In: Staeheli, L., Kofman, E. and Peake, L. J. (eds) Mapping women, making politics: feminist perspectives on Political Geography. New York: Routledge, pp. 113-125.

Gottman, J. (1951). Geography and International Relations. World Politics 3, pp. 153-173.

Gregory, D. (2004). The colonial present: Afghanistan, Palestine, Iraq. Oxford, UK: Blackwell.

Gregory, D., and Pred, A. (eds) (2007). Violent geographies: fear, terror, and political violence. New York: Routledge.

Grundy-Warr, C. (1994). Towards a political geography of United Nations peacekeeping: some considerations. GeoJournal 34, pp. 177-190.

Gurr, T. R. (2000). Ethnic warfare on the wane. Foreign Affairs 79 (3), pp. 52-64.

Hale, A., and Opondo, M. (2005). Humanising the cut flower chain: confronting the realities of flower production for workers in Kenya. Antipode 37, pp. 301-323.

Harbom, L., and Wallensteen, P. (2005). Armed conflict and its international dimensions, 1946-2004. Journal of Peace Research 42, pp. 623-635.

Harvey, D. (2003). The new imperialism. Oxford, UK: Oxford University Press.

Herod, A., Ó Tuathail, G., and Roberts, S. (1998). Unruly world? Globalization, governance and geography. London: Routledge.

Hirst, P. (2005). Space and power: politics, war and architecture. Cambridge, UK: Polity.

Holder, J., and Harrison, C. (eds) (2003). Law and geography. Oxford, UK: Oxford University Press.

Hudson, B. (1977). The new geography and the new imperialism, 1870-1918. Antipode 9 (2), pp. 12-19.

Hughes, A. (2001). Global commodity networks, ethical trade and governmentality: organizing business responsibility in the Kenyan cut flower industry. Transactions of the Institute of British Geographers 26, pp. 390-406.

Human Security Centre. (2005). Human security report 2005: War and peace in the twenty-first century. Oxford, UK: Oxford University Press.

Hyndman, J. (2000). Managing displacement: refugees and the politics of humanitarianism. Minneapolis, MN: University of Minnesota Press.

- (2004). Mind the gap: bridging feminist and political geography through geopolitics. Political Geography 23, pp. 307-322.

Ietto-Gillies, G. (2002a). Transnational corporations: fragmentation amidst integration. London: Routledge.

- (2002b). How internationalized are EU transnationals? Journal of Interdisciplinary Economics 13, pp. $13-49$.

International Labour Office. (2007). Safe and healthy workplaces: making decent work a reality: the ILO report for World Day for Safety and Health at Work. Geneva: International Labour Organisation.

Jochnick, C. (1999). Confronting the impunity of non-state actors: new fields for the promotion of human rights. Human Rights Quarterly 21, pp. 56-79. 
Kearns, G. (2006). Naturalising empire: echoes of Mackinder for the next American century? Geopolitics 11, pp. 74-98.

- (forthcoming). Geopolitics and empire: the legacy of Halford Mackinder. Oxford, UK: Oxford University Press.

Kearns, G., and Reid-Henry, S. (forthcoming). Vital geographies: life, longevity, and geographical luck. Annals of the Association of American Geographers.

Klare, M. T. (2001). Resource wars: the new landscape of global conflict. New York: Henry Holt.

Klein, N. (2007). The shock doctrine: the rise of disaster capitalism. London: Penguin.

Kleveman, L. C. (2003). The new Great Game: blood and oil in Central Asia. New York: Atlantic Monthly Press.

Kliot, N., and Waterman, S. (eds) (1991). The political geography of conflict and peace. London: Belhaven.

Klooster, D. (2006). Environmental certification of forests in Mexico: the political ecology of a nongovernmental market intervention. Annals of the Association of American Geographers 96, pp. 541-565.

Kurlansky, M. (2006). Nonviolence: twenty-five lessons from the history of a dangerous idea. New York: Modern Library.

Lacoste, Y. (1976). La géographie, ça sert d'abord, à faire la guerre [Geography is primarily for making war]. Paris, France: François Maspero.

- (2005). 'Hérodote' et Reclus. Hérodote 117, pp. 5-9.

Mackinder, H. J. (1919). Democratic ideals and reality: a study in the politics of reconstruction. London: Constable.

Malpass, A., et al. (2007). Fairtrade urbanism? The politics of place beyond place in the Bristol Fairtrade City campaign. International Journal of Urban and Regional Research 31, pp. 633-645.

Mamadouh, V. D. (1998). Geopolitics in the nineties: one flag, many meanings. GeoJournal 46, pp. 237-253.

Marshall, M. G., and Goldstone, J. (2007). Global report on conflict, governance and state fragility 2007. Foreign Policy Bulletin 17 (Suppl. 1), pp. 3-21.

Marx, K. (1973 [1864]). Inaugural address of the International Working Men's Association. In: Marx, K. (ed.) The First International and after: political writings, Vol. 3. Harmondsworth, UK: Penguin, pp. 73-81.

McDonald, H. (2003). Cheney's tough talking derails negotiations with North Korea. Sydney Morning Herald 22 December. [online]. Retrieved on 3 November 2007 from http:// www.smh.com.au/articles/2003/12/21/1071941611806.html

McDougall, D. (2007). Indian 'slave' children found making low-cost clothes destined for Gap. Observer 28 October. [online]. Retrieved on 29 October 2007 from http:// observer.guardian.co.uk/world/story/0,2200590,00.html

McFarlane, C. (2006). Crossing borders: development, learning and the North-South divide. Third World Quarterly 27, pp. 1413-1437.

McIlwaine, C. (1998). Civil society and development geography. Progress in Human Geography 22, pp. 415-424.

- (1999). Geography and development: violence and crime as development issues. Progress in Human Geography 23, pp. 453-463.

Mearsheimer, J. (2001). The tragedy of great power politics. New York: W. W. Norton.

Mendieta, E. (2006). War the school of space: the space of war and the war for space. Ethics, Place and Environment 9, pp. 207-229.

Mercer, C. (2002). NGOs, civil society and democratization: a critical review of the literature. Progress in Development Studies 2, pp. 5-22.

Meyer, C. (2007). Fighting for a new homeland: US Army lures foreigners with promise of citizenship. Spiegel Online International 19 October. [online]. Retrieved on 29 October 2007 from http://www.spiegel.de/international/world/0,1518,512384,00.html

Miller, B. A. (2000). Geography and social movements: comparing anti-nuclear activism in the Boston area. Minneapolis, MN: University of Minnesota Press.

Mohan, G. (2002). The disappointments of civil society: the politics of NGO intervention in Northern Ghana. Political Geography 21, pp. 125-154.

Moody, R. (1996). Mining the world: the global reach of Rio Tinto zinc. Ecologist 26 (2), pp. $46-52$. 
Moon, J. D. (2003). Rawls and Habermas on public reason: human rights and global justice. Annual Review of Political Science 6, pp. 257-274.

Moravcsik, A. (2002). Reassessing legitimacy in the European Union. JCMS: Journal of Common Market Studies 40, pp. 603-624.

Morgenthau, H. (1993 [1948]). Politics among nations: the struggle for peace and power. New York: McGraw-Hill.

Müller, M. (2008). Reconsidering the concept of discourse for the field of critical geopolitics: towards discourse as language and practice. Political Geography 27, pp. 323-338.

Mustafa, D. (2005). The terrible geographicalness of terrorism: reflections of a hazards geographer. Antipode 37, pp. 72-92.

Nagel, T. (2005). The problem of global justice. Philosophy and Public Affairs 33, pp. 113-147.

Nevins, J. (2003). Restitution over coffee: truth, reconciliation, and environmental violence in East Timor. Political Geography 22, pp. 677-701.

Newman, D. (1996). Introduction: postmodernity and the territorial discourse of peace. GeoJournal 39, pp. 327-330.

Nye, J. S. (2004). Soft power: the means to success in world politics. New York: Public Affairs.

O'Loughlin, J. (1986). Political Geography: tilling the fallow field. Progress in Human Geography 10 , pp. 69-83.

O'Loughlin, J., and van der Wusten, H. (1986). Geography, war and peace: notes for a contribution to a revived Political Geography. Progress in Human Geography 10, pp. 326-352.

O'Rourke, D. (2003). Outsourcing regulation: analyzing nongovernmental systems of labor standards and monitoring. Policy Studies Journal 31, pp. 1-29.

Oslender, U. (2004). Fleshing out the geographies of social movements: black communities on the Colombian Pacific coast and the aquatic space. Political Geography 23, pp. 957-985.

Ó Tuathail, G. (1987). Beyond empiricist Political Geography: a comment on van der Wusten and O'Loughlin. Professional Geographer 39, pp. 196-197.

- (1994). (Dis)placing geopolitics: writing on the maps of global politics. Environment and Planning D: Society and Space 12, pp. 525-546.

- (1996). Critical geopolitics: the politics of writing global space. Minneapolis, MN: University of Minnesota Press.

Peattie, R. (1944). Look to the frontiers: a geography for the peace table. New York: Harper.

Pepper, D. (1985). Introduction: geographers in search of peace. In: Pepper, D. and Jenkins, A. (eds) The geography of peace and war. Oxford, UK: Basil Blackwell, pp. 1-10.

Pepper, D., and Jenkins, A. (1983). A call to arms: geography and peace studies. Area 15, pp. 202-208.

. (eds) (1985). The geography of peace and war. Oxford, UK: Basil Blackwell.

Pickerill, J., and Webster, F. (2006). The anti-war/peace movement in Britain and the conditions of information war. International Relations 20, pp. 407-423.

Purcell, M., and Nevins, J. (2005). Pushing the boundary: state restructuring, state theory, and the case of U.S.-Mexico border enforcement in the 1990s. Political Geography 24, pp. 211-235.

Redfield, P. (2005). Doctors, borders, and life in crisis. Current Anthropology 20, pp. 328-361.

- (2006). A less modest witness: collective advocacy and motivated truth in a humanitarian movement. American Ethnologist 33, pp. 3-26.

Roberts, S., and Schein, R. (1995). Earth shattering: global imagery and GIS. In: Pickles, J. (ed.) Ground truth: the social implications of Geographic Information Systems. New York: Guilford Press, pp. 171-195.

Robertson, G. (2006 [1999]). Crimes against humanity: the struggle for global justice, 3rd ed. London: Penguin.

Rosencranz, A., and Louk, D. (2005). Doe v. Unocal: holding corporations liable for human rights abuses on their watch. Chapman Law Review 8, pp. 135-152.

Routledge, P. (2003). Nonviolent social movements and the contestation of place in India. Westport, CT: Praeger.

Ruggie, J. G. (2002). The theory and practice of learning networks: corporate Social Responsibility and the Global Compact. Journal of Corporate Citizenship 5, pp. 27-36.

Sadler, D. (2004). Anti-corporate campaigning and Corporate 'Social' Responsibility: towards alternative spaces of citizenship? Antipode 36, pp. 851-870.

Scahill, J. (2007). Blackwater: the rise of the world's most powerful army. New York: Nation Books. 
Schell, J. (2003). The unconquerable world: Power, non-violence, and the will of the people. London: Allen Lane.

Schlesinger, S., and Kinzer, S. (1982). Bitter fruit: the untold story of the American coup in Guatemala. Garden City, NY: Doubleday.

Seabrook, J. (2001). Children of other worlds: exploitation in the global market. London: Pluto.

Simms, B. (2001). Unfinest hour: Britain and the destruction of Bosnia. London: Penguin.

Slater, D. (2004). Geopolitics and the post-colonial: rethinking North-South relations. Oxford, UK: Blackwell.

Sluglett, P. (1976). Britain in Iraq: 1914-1932. London: Ithaca Press.

Smith, J., and Wiest, D. (2005). The uneven geography of global civil society: national and global influences on transnational association. Social Forces 84, pp. 621-652.

Smith, M. J. (1998). Humanitarian intervention: an overview of the ethical issues. Ethics and International Affairs 12, pp. 63-79.

Smith, N. (1992). Real wars, theory wars. Progress in Human Geography 16, pp. 257-271.

Smith, R. (2005). The utility of force: the art of war in the modern world. London: Allen Lane.

Spykman, N. J. (1942). Frontiers, security, and international organization. Geographical Review 32, pp. 436-447.

-. (1944). The geography of the peace. New York: Harcourt, Brace and Co.

Steers, H. G. (1948). Review of van Valkenburg (1946) and Dixon (1946). International Affairs 24, p. 431.

Stoddart, D. R. (1992). Geography and war: the 'new geography' and the 'new army' in England, 1899-1914. Political Geography 11, pp. 87-99.

Sundberg, J. (1998). NGO landscapes: conservation and communities in the Maya Biosphere Reserve, Peten, Guatemala. Geographical Review 88, pp. 388-412.

Taylor, E. G. R. (1948). Geography in war and peace. Geographical Review 38, pp. 132-141.

Taylor, P. J. (2000). Embedded statism and the social sciences 1: geographies (and metageographies) in globalization. Environment and Planning A 32, pp. 1105-1114.

- (2004). The new geography of global civil society: NGOs in the world city network. Globalizations 1, pp. 265-277.

Teggart, F. (1919). Geography as an aid to statecraft: an appreciation of Mackinder's 'Democratic Ideals and Reality'. Geographical Review 8, pp. 227-242.

Terry, F. (2002). Condemned to repeat? The paradox of humanitarian action. Ithaca, NY: Cornell University Press.

Townsend, J., Porter, G., and Mawdesley, E. (2002). The role of the transnational community of development non-governmental organizations: governance or poverty reduction. Journal of International Development 14, pp. 829-839.

Traub, J. (2006). The best intentions: Kofi Annan and the UN in the era of American power. London: Bloomsbury.

Urquhart, B. (2007). Limits on the use of force. In: Croker, C. A., Hampson, F. O. and Hall, P. (eds) Leashing the dogs of war: conflict management in a divided world. Washington, DC: United States Institute of Peace Press, pp. 265-276.

van der Wusten, H., and O'Loughlin, J. (1986). Claiming new territory for a stable peace: how Geography can contribute. Professional Geographer 38, pp. 18-28.

Van Valkenburg, S. (1946). Peace atlas of Europe. New York: Duell, Sloan, and Pearce.

Vašák, K. (1977). A thirty-year struggle: the sustained efforts to give force of law to the Unviersal Declaration of Human Rights. UNESCO Courier 30 (11), pp. 28-29, 32.

Wallach, L., Woodall, P., and Public Citizen (2004). Whose trade organization? A comprehensive guide to the WTO. New York: New Press.

Wapner, P. (1996). Environmental activism and world civic politics. New York: City University of New York Press.

Watts, M. (1983). Silent violence: food, famine and peasantry in Northern Nigeria. Berkeley, CA: University of California Press.

Weidhorn, M. (1997). A contrarian's approach to peace. In: Muller, J. W. (ed.) Churchill as peacemaker. Cambridge, UK: Cambridge University Press, pp. 24-53.

Wheeler, N. J. (2000). Saving strangers: humanitarian intervention in international society. Oxford, UK: Oxford University Press.

Wisner, B. (1986). War or peace studies. Antipode 18, pp. 212-217.

Yergin, D. (1991). The prize: the epic quest for oil, money, and power. New York: Free Press. 